\title{
Hélène Cixous
}

Dreamer, realist, analyst, writing 


\section{Hélène Cixous}

\section{MANCHESTER 1824}

Manchester University Press 
Nicholas Royle - 9781526140678 Downloaded from manchesterhive.com at $04 / 26 / 2023$ 11:30:57AM via free access 


\title{
Hélène Cixous
}

\section{Dreamer, realist, analyst, writing}

\author{
Nicholas Royle
}

Manchester University Press 
Copyright (c) Nicholas Royle 2020

The right of Nicholas Royle (b. 1957) to be identified as the author of this work has been asserted by him in accordance with the Copyright, Designs and Patents Act 1988.

Published by Manchester University Press

Altrincham Street, Manchester M1 7JA

www.manchesteruniversitypress.co.uk

British Library Cataloguing-in-Publication Data

A catalogue record for this book is available from the British Library

ISBN 9781526140661 hardback

First published 2020

The publisher has no responsibility for the persistence or accuracy of URLs for any external or third-party internet websites referred to in this book, and does not guarantee that any content on such websites is, or will remain, accurate or appropriate.

Cover credit: Rembrandt, 'An old woman reading' (1655). The Buccleuch Collections

Cover design: Abbey Akanbi, Manchester University Press

Typeset in Minion Pro by

Servis Filmsetting Ltd, Stockport, Cheshire 